\title{
Foreign and Reserve Life Hand in Hand: Nation with in a Nation in Tomson Highway's The Rez Sisters
}

\section{Maggy Clemence}

B.ED, English ( $4^{\text {th }}$ semester), Calicut University Teacher Education Centre, Koduvur, Palakkad, Kerala, India.

\begin{abstract}
This papers focus on the dual existence of the concept of Nationality which is generally referred as the "Nation with in a Nation". When we trace the early orgins of Canada, the result would be a wide separation of two cultures, the reserve culture and the foreign culture. One such division is further reflected in 'The Res Sisters' a famous work by Cree Canadian writer Tomson Highway. The plot revolves around the life of seven sisters who were subjected to reserve life. Their life wasn't a bed of roses, their hurdles that was artificially created by the white immigrants.The play glorifies the rebellious attitude of the reserve ladies, the intervention of a male counterpart named Nanabush. Nanabush itself is the blurred conscious minds of the woman whose support heals their wounds. Race and ethnicity can also be implored further to stress the discrimination with in the Nation.
\end{abstract}

Keywords - Nation with in a nation, Race and Ethnicity, Discrimination, Cultural Limitations.

\section{INTRODUCTION}

Literature has always been a medium that lucidly reflects the depth and vastness of human culture. Pictorial representation of social images and events has been along standing formula for Canadian drama. 'The Res sisters' is a two act play by Cree Canadian writer Tomson Highway, first performed on November 26, 1986 by Act4 Theatre Company and Native Earth Performing Arts. The play is partially inspired by Michael Trimplay's 'Les Belles Soeurs'. Tomson Highway is an Aboriginal Canadian playwright, novelist and children's author. He is best known for his plays 'The Rez Sisters' and 'Dry Lipe Oughta Move to Kapuskasing' ,both of which won him the Dora Mavor Moore Award and the Floyd .S .Chalmers Award. Highway explores the Canadian audience by educating and entertaining the reality of reservation life; the brutality of a system that rejects or sentences native people to live of society spiritual poverty that takes away from their pride, tradition and their language. The play is set in a fictional reserve on Manitoulin Island, Ontario, Canada. Featuring an ensemble cast, the play is about a group of seven women dreaming of winning and raising enough money to participate The Biggest Bingo in the World. Nanabush is the only one male character who played the role as trickster. The comparison of reserved life with that of foreign life is the central theme for some of Canadian works which gained an immense position in the field of both English as well as Canadian Literature. The play won1986-87 Dora Mavor Award for Outstanding New play, winner of the Floyd .S. Chalmers Canadian Play Award in 1987 an dominated for Governor General's Award for English Language Drama in 1988. In 2010 Highway staged Iskooniguni Iskweewuk, a Cree language version of the play.

\section{POTRAYAL OF THE PLAY}

The plot of the play is simple and linear but the portrayal of characters revelation and depiction is complicated.The different personalities of each character in 'The Rez Sisters' interweave audience at different attitude towards their life and role on the reservation. The seven women's [Pelajia Patchnose, Philomena Moosetail, Marie-Adele Starblanket, Zhaboonigan Peterson, Veronique St. Pierre, Emily Dictionary, Annie Cook] arranged a road trip from their reserve to Toronto to participate in The Biggest Bingo in the World. Every human nature belongs to their own ambitions and fortunes. Likewise each women in the play has their own 
dreams and hopes in winning the Bingo jackpot and what life will bring changing fortunes in them. These characters displayed the natural desire to rise above their surroundings and create environment for their children and future generation. Although the reserve can be viewed as a place of misery, with little hope and wishes. Rez sisters has their own personal demons, tragedies and hopes that winning the Bingo game will be the answer to all their problems.

The play opens with Pelajia who reveals her desire to escape from her disdainful life. The dreams of pelajia is much more difficult to fertile, she uses a hammer to threaten people.At the end her hammer has become a badge of purpose rather than just a physical tool. Philomena's story is a victory of simple needs and simple dreams. Philomena dreams only of winning bingo, so that she can build a new toilet It is later revealed that Phelomena conceived a child after having an affair with her boss, who eventually abundant her. Both she and her sister Pelajia remained trapped on the reserve. She is the only one who won some money at the bingo. The varied task of characters include Marie Adele mainspring of the play who has fourteen children and her dreams of an idyllic Island home in Georgian Bay forher husband Eugene and children's. Later was diagnosed that she is a victim of cancer and it expresses her true fears to die. She optimistically believe that her husband will take care of her children's. Annie Cook, older sister of Marie Adele and half sister of Pelajia and Phenomena, lost Eugene to her own sister Marie Adele. Annie has unrealistic hope of being a country singer and marry Fritz a Jewish country musician a dream that might be easier to accept if she could sing. Emily Dictionary sister of Annie is an unappealing character works in the local store and a rough ex-biker who lost her lesbian lover in a tragic motor cycle accident, although previously married with a husband who abused her and almost killed her. She offers conflict between the characters. At the end of the play Emily became pregnant and beautifully transferred as a loving sister to Zhaboonigan and a loving mother to her baby .Veronique is sister in law of Emily Dictionary, she is disliked by almost everybody and has equal sources of distress in her life. She adopted Zhaboonigan (a mentally disabled daughter) with her husband and an predictable stove. At the end of the play she gets new stove that she has been wanting. She uses it to cook for Eugene, widower of Marie-Adele, and his children. Zhaboonigan was sexually abused [screwdriver] by two white rapist and carries the brutal burden with herself. Nanabuh is the only male character who is also known as trickster, who is a

ISSN: 2456-7620

https://dx.doi.org/10.22161/ijels.53.26 mythological spirit that observes the action of the play [.Zhaboonigan is the only one who can able to see Nanabush]

The play recounts and overcome several diversions and obstacles of rez sisterson the way to Toronto . During their exchange of stories each characters emotional and personal sufferings have been heightened. The audience gets to know about these women's ,their stories and able to see how they treat each other. Even, when they argue and fight each other ,they lookout for one another the bond of sisterhood transcends all racial labels and material objects. As the play comes to an end the audience came to know the major themes such as Nation with in a Nation, race and ethnicity, cultural limitations are clearly portrayed including home as a element where every human heart is. This play also accounts how these group of women learn to respect each other and place where they leave, ,rather than running off to a new unfamiliar place and also indicate how human nature should respect each other.

\section{MANIFESTATION OF THEMES}

Nation with in a Nation, race and ethnicity, discrimination, cultural limitations are the major, concepts or main elements of the play. A peep in to the life of these seven woman's depicts the cultural limitations and a clear representation of how they suffer and survey life as a reserve being. While race and ethnicity are considered to be separate phenomenon in the contemporary social science, the two terms have a long history of equivalence in popular usage and older social science literature. Whereas racism and racial discrimination are used to describe discrimination of an ethnic or cultural basis, independent of whether these differences are described as racial. According to United Nation convention, there is no distinction between the terms 'racial discrimination' and 'ethnic discrimination'. Dramas have always carried and propagated messages against such stereotypes, by depicting the lives of various racially marginalized peoples. The Rez Sisters is the finest example for this.

\section{CONCLUSION}

Highway did a great job by giving the reader an idea of what reserve life is about. He gave us the opportunity to experience the hardship of native people and some insight to how they form their identity. Nanabush had a great deal to do with the women keeping their current identities .I feel that if we believe in a spirit and surrender or lives to them they will 
take care of us just as Nanabush did in this play .As human beings we need to open our eyes and see we can all belong together and live in one society without dropping our culture that will end cultural limitations, ,race and ethnicity such stereotyping. These are the main factors that push people, more commonly native people, in to the loss of belongings ,the loss of their culture and the loss of the core of their identity.

\section{REFERENCES}

[1] Cree "Encyclopedia of North America Indian ED1996:546548.

[2] Highway Tomso,. "The Rez Sisters". The Broadway Anthology of Drama: Plays from the Western Theater. Jennifer Wise and Craig S. Walker. Canada: Broadview Press, 2003.515-546.

[3] Highway Tomson ,.'The Rez Sisters' Postcolonial Plays Helen Gilbert . London: Rout ledge, 2001.390-394.

[4] Krasner, David,. "The Rez Sisters". Theatre Journal Vol.46, No.3, (Oct, 1994):399-400.

[5] Richard, David,. "The Rez Sisters, Bingo as the way of Escape.”The New York Times. $5^{\text {th }}$ January, 1994. 